\title{
Knowledge, Practices and Challenges on HIV/AIDS Among High School Students in Wombera District, Benishangul Gumuz, Ethiopia
}

\author{
Silenat Birhanu ${ }^{1} \quad$ Fikadu Kumsa $^{2 *} \quad$ Mathewos Temesgen $^{2}$ \\ 1.Wombera Secondary \& Preparatory School, Benishangul Gumuz, Ethiopia \\ 2.Department of Biology, College of Natural and Computational Science, Ambo University, Ethiopia
}

\begin{abstract}
Human Immunodeficiency virus, commonly known as HIV infects the cells of human immune system and destroys them which later develop into an advanced condition called Acquired Immunodeficiency Syndrome. The aim of this study is to assess the knowledge, practices and challenges of HIV/AIDS infection and prevention among some selected high school students of Wombera district, Benishangul Gumuz, Ethiopia. Simple random sampling method was used to select the representative population. The data were collected through the multistage based close-ended and, open ended questionnaires. In addition, secondary data were collected through document observation. Among the total respondents, 46(38\%) males and 45(37.2\%) females know as HIV/AIDS is sexually transmitted disease. Generally, the results indicated that most of the students were aware of about the methods of transmission and prevention of HIV/AIDS infection. In spite of the high level of knowledge, there were also misconception and assumption toward the transmission methods of HIV/ AIDS infection.
\end{abstract}

Keywords: HIV/AIDS, Knowledge, Practice, Students, Secondary High Schools

DOI: $10.7176 /$ ALST/79-03

Publication date:March $31^{\text {st }} 2020$

\section{INTRODUCTION}

Human Immunodeficiency virus, commonly known as HIV, is a retrovirus that infects cells of the immune system by destroying or impairing their function leading to increased susceptibility to infections and which later develops into an advanced condition called Acquired Immunodeficiency Syndrome (AIDS) (Kline, 2014). AIDS is the final stage of HIV infection, and at this stage, it is necessary for victims to seek medical attention in order to prevent death and this condition declines the capacity of human body to fight against the diseases make the person vulnerable to all kind of infections which may eventually lead to death (Taher \& Abdelhai, 2011). Since the first HIV case was recognized in the United States in 1981, it has spread rapidly throughout the world (Shiferaw et al., 2011). The first case of HIV in Ethiopia was reported in 1984. HIV prevalence varies with age, sex, and geographical location (Shiferaw et al., 2011).

Viewing adolescents as a specific group with their own needs is relatively a recent practice, especially in developing countries. Similarly, adolescents aged 10 to 20 years constitute $25 \%$ of the population in Ethiopia (Okonkwo et al., 2005). According to the study of Agajie et al., 2015, young people are a significant part of the labor force and form the backbone of any country's economy. These groups are at high risk of HIV for a variety of reasons, such as lack of knowledge about HIV, not perceiving themselves to be at risk, lake of access to or inconsistent use of condom, increased number of sexual partners increased risk of exposure, biological factors (their cervical epithelium is more susceptible to infection), economic factors, social factors, being forced in to asexual relationship, lacking the skills and power to negotiate condom use and encountering gender norms. The health of young people is thus a key element for social and economic progress. Neglecting the sexual and reproductive health of young people can lead to high social and economic costs, both immediately and in the years ahead (WHO, 2002). According to Wombera woreda Healthy Office HIV/AIDS Prevention and control Case Team report 2017, the prevalence of HIV/AIDS in Benshangul Gumuz Region is about $0.61 \%$. This shows that the prevalence of HIV/AIDS in the region is decreasing as compared to the 2011 EHDS report. High school students' knowledge about HIV/ AIDS might be varies by their socio-demographic characteristics such as age, gender, school type, family head income, and source of information. The study of knowledge of HIV/AIDS is considered a basic first step in the education process and prevention of the disease (Huda \& Amanullah, 2013).Secondary school students' knowledge and practice (KP) on HIV/AIDS can be an indicator of the magnitude of the problem among youths. However, the knowledge and practice toward HIV/AIDS infection and prevention in Wombera secondary school students has not been studied so far. So, it is prudent to conduct this study among three selected secondary school students in this district in order to ascertain their knowledge and practice regarding HIV/AIDS. The study is also used to identify the extent of risk behavior and practice exposed to HIV/AIDS among students and to describe the relationship between the socio-demographic and economic characteristics with risk behavior related to HIV/AIDS. 


\section{MATERIALS AND METHODS}

Description of the Study Area

Wombera is one of the 20 Districts in the region and one of the seven Districts in Metekel zone of Benishanigule Gumuze region of Ethiopia. Its administrative town is Deberzeit which is located at 100 35'53" north latitude and 350 59' 51" east longitude (facts about Benishangul-Gumuz annually published bulletin by government communication affairs bureau, 2013). The district is located in western Ethiopia, Benishangul Gumuz National Regional state on $658 \mathrm{~km}$ away from Addis Ababa toward West. The district is enclosed between Bullen District by the East, Dangure District by North-East, Yaso District by the South-East, Agalo-Meti District by the South, Sirba Abay District by the South-West and Guba near the biggest Ethiopian renaissance dam. This district is the wettest district with the annual rainfall ranges from $900 \mathrm{ml}-1500 \mathrm{ml}$. In the dry season maximum daily temperature reaches to $20-35^{\circ} \mathrm{c}$ and the coldest period minimum temperature range $12-20^{\circ} \mathrm{c}$ depending on altitude season. The three selected high schools are Wombera high school is located in Debre-Zite which is town of the district; Senkora high school 7 kilo meter from the central town and Sanki high school has also the same distant from the town (Figure-1).

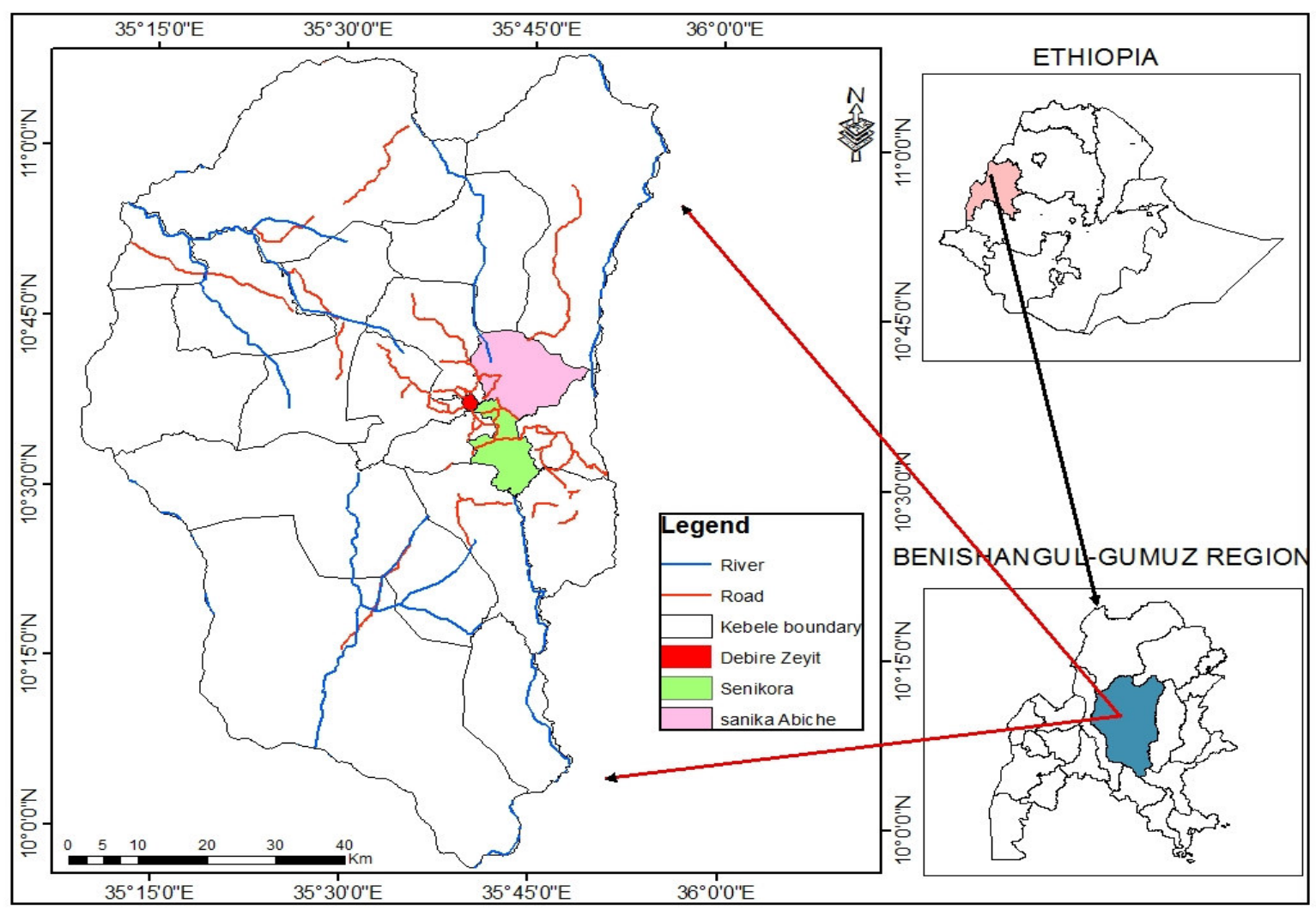

Figure 1: Map of study area

\section{Study design}

A descriptive cross sectional survey method was used to collect the data. Quantitative data approach was applied to collect data from questionnaire and analyzed those collected data survey using descriptive approach. A qualitative method was also applied to collect data from key informants such as Kebele administrators and other members and youth representatives.

\section{Sample size determination and sampling techniques}

The populations of this study were students in three different high schools of Wombera District. Thus groups were used with the assumption that, they are sexually active and highly engaged in heterosexual activity, which is the main reason for HIV transmission among sexually active Ethiopian population (Negash et al, 2003). So the population number were 593 in Wombera high school, 204 in Senkora high school, and 154 in Sanki high school. So the total population was 951.For primary data collection, the representative samples of students were taken using Kothari (2004) formula: Based on the calculation, the population number of sample size selected were 593, 204 and 154from Wombera, Senkora, and Sanki high Schools, respectively. 


\section{Data collection method}

Both primary and secondary data sources were used for the study. The sources of primary data of this study were students from secondary schools. The data gathering tools were close-ended, open ended questionnaires. Before the starting of data collection, the questionnaires were pretest on $10 \%$ of the students that did not included in main sampling population. Pilot test or pretest is a feasibility study which are "small scale version, trial run, done in preparation for the major study" (LoBiondo \& Haber, 2017). This is important to check the validity of the questions used to remove or exclude vague or ambiguous questions which were not easily answered by students. The questionnaire was prepared based on the available literature reviewed to elicit HIV/AIDS knowledge and sexual practices. Questions that access the knowledge and challenge in prevention of HIV/AIDS in the study areas were prepared. The questions were prepared by English language and translated in to Amharic language by language experts in order to make more understandable for the respondents.

\section{RESULTS}

\section{Socio demographic characteristics}

Of the total respondents $47.9 \%(n=58)$ were male and $52.1 \%(n=63)$ were female. Of these, were $62 \%(n=75)$ were from Wombera high school, 21.5\% $(n=26)$ were from Senkora high school and $16.5 \%(n=20)$ were from Sanki high school. Of the total respondents, majority of the males $28.9 \%(n=35)$ involved in the study were found in the age group between 15-17 years old followed by the age group between 18-20 year old. Similarly, majority of the females $37.2 \%(n=45)$ were found in the age group between 15-17 years old.

The result indicated that about $66.1 \%(n=80)$ of the students in the study area were found in the age range of 15-17 year old (Table-1).

Table 1: The gender and age based distribution of the respondents selected from three high schools of Wombera District $(\mathrm{n}=121)$.

\begin{tabular}{|c|c|c|c|c|}
\hline \multirow[t]{2}{*}{ Variables } & \multirow[t]{2}{*}{ Response } & \multicolumn{2}{|c|}{ Sex of respondents } & \multirow[b]{2}{*}{ Total (\%) } \\
\hline & & Male (\%) & $\begin{array}{l}\text { Female } \\
(\%)\end{array}$ & \\
\hline \multirow[t]{3}{*}{ Schools } & Wombera high school & $35(28.9 \%)$ & $45(33.1 \%)$ & $75(62 \%)$ \\
\hline & Senkora high school & $14(11.2 \%)$ & $12(10 \%)$ & $26(21.5 \%)$ \\
\hline & Sanki high school & $9(7.4 \%)$ & $11(9.1 \%)$ & $20(16.5 \%)$ \\
\hline \multirow[t]{2}{*}{ Grade level } & $9^{\text {th }}$ & $30(24.8 \%)$ & $33(27.3 \%)$ & $63(52.1 \%)$ \\
\hline & $10^{\text {th }}$ & $28(23.1 \%)$ & $30(24.8 \%)$ & $58(47.9 \%)$ \\
\hline Age of & $15-17$ & $35(28.9 \%)$ & $45(37.2 \%)$ & $80(66.1 \%)$ \\
\hline \multirow[t]{2}{*}{ respondents } & $18-20$ & $23(19 \%)$ & $15(12.4 \%)$ & $38(31.4 \%)$ \\
\hline & Above 20 & 0 & $3(2.5 \%)$ & $3(2.5 \%)$ \\
\hline
\end{tabular}

Of the total respondents, about $(63 \%(n=76), 29 \%(n=35), 7 \%(n=9)$ and $0.8 \%(n=1)$ of them live with their families, friends, alone and partner, respectively (Figure.3).

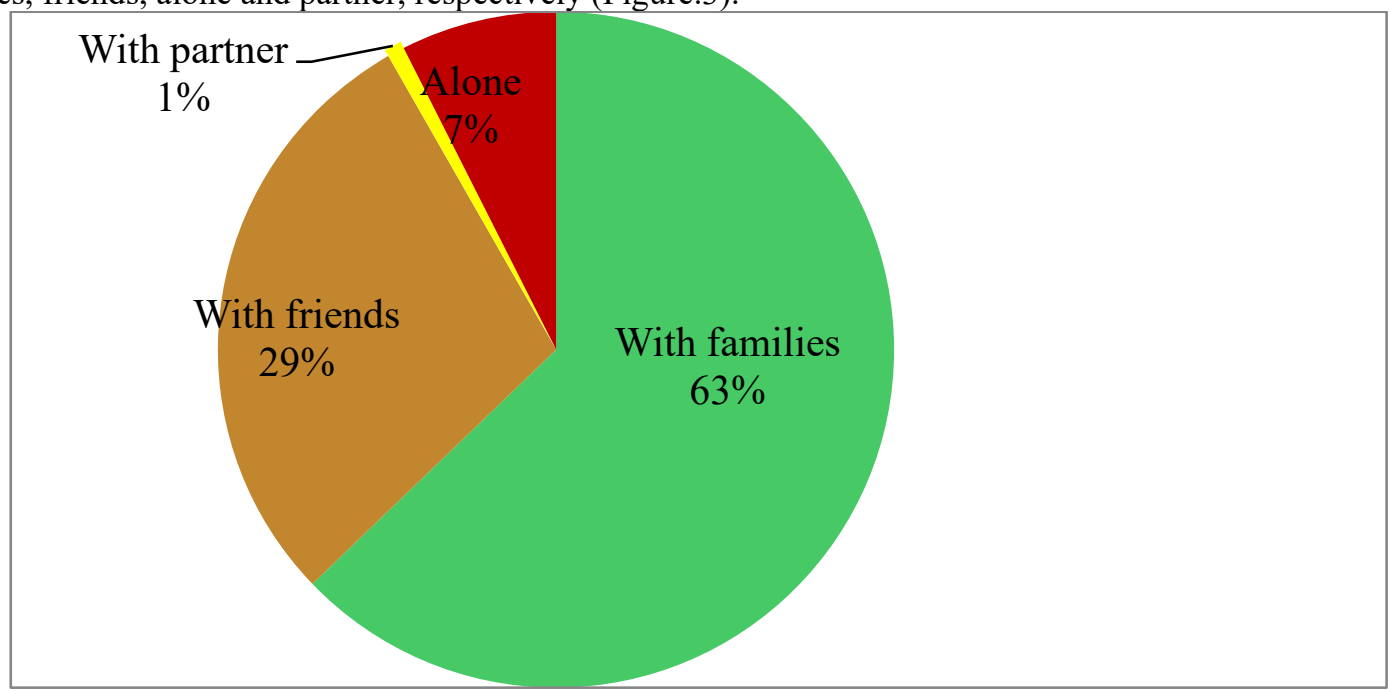

Figure 2: The respondent student's life distribution during their study time

The result of chi-square indicates that, $\left(\mathrm{x}^{2}=1.288, \mathrm{p}<0.526\right)$ this specifies that the respondents in study area (the three high schools) have no significant difference regarding open discussion about HIV/AIDS issues with their parents (Table-2). 
Table 2: The habit of respondents' behavior regarding to discussion about HIV/AIDS with their parents in the selected high schools of Wombera District $(n=121)$.

\section{Habit of discussion about HIV/AIDS issues with parents}

\begin{tabular}{lllllll} 
Schools & Yes & No & Total & Value & Df & $\begin{array}{c}\text { Chi-square test } \\
\text { Significant }\end{array}$ \\
\hline Wombera & $29(24 \%)$ & $46(38 \%)$ & $75(62 \%)$ & & & \\
Senkora & $7(5.8)$ & $19(15.7 \%)$ & $26(21.5 \%)$ & & & \\
Sanki & $8(6.6)$ & $12(9.9 \%)$ & $20(16.5 \%)$ & 1.288 & 2 & 0.525
\end{tabular}

\section{Knowledge of respondents about mode of HIV/AIDS transmission and prevention}

Among the total respondents, 38\% $(n=46)$ males and $37.2 \%(n=45)$ females of the respondents know that HIV/AIDS is sexually transmitted disease, whereas about $7.4 \%(n=9)$ males and $13.2 \%(n=16)$ females of the respondents do not know as HIV/AIDS is the sexually transmitted disease. The result of the respondents' knowledge about transmission of HIV/AIDS also revealed that, about $79.3 \%(n=96)$ of them know very well as HIV transmit through an injection of needle that was used by HIV/AIDS positive person. Similarly, majority of them $59.5 \%(\mathrm{n}=72)$ have an awareness as HIV can transmitted from infected pregnant mother to child. In other words, about $24 \%(n=29)$ males, $24.8 \%(n=30)$ females of the respondents mentioned that HIV can be transmitted by eating raw meat prepared by HIV infected person. Similarly, most of the respondents $19 \%(\mathrm{n}=23)$ males and $33 \%(n=40)$ females) responded that HIV can transmitted through touching saliva or sweat of HIV infected person, and $21.5 \%(n=26)$ males and $14 \%(n=17)$ females mentioned that HIV can be transmitted through mosquito bite. As the result indicates, there is no significant difference on knowledge of HIV/AIDS transmission methods, but it also shows as there is significant difference in HIV/AIDS transmission through mosquito bite in both male and female students which indicates $\left(X^{2}=8.292, \mathrm{p}>0.016\right)$ (Table-6).

Table 3: The distribution of respondents' knowledge about the mode of HIV/AIDS transmission of respondents selected from the three high schools of Wombera District $(n=121)$.

\begin{tabular}{|c|c|c|c|c|c|c|c|c|c|}
\hline \multirow[b]{2}{*}{$\begin{array}{c}\text { Knowledge about HIV and } \\
\text { its transmission }\end{array}$} & \multicolumn{3}{|c|}{ Male } & \multirow[b]{2}{*}{ Yes } & \multicolumn{2}{|l|}{ Female } & \multicolumn{3}{|c|}{ Chi-square } \\
\hline & Yes & No & $\begin{array}{l}\text { I don't } \\
\text { know }\end{array}$ & & No & $\begin{array}{l}\text { I don't } \\
\text { know }\end{array}$ & Value & df & $\mathbf{P}$ \\
\hline Is HIV STD & $46(38)$ & $9(7.4)$ & $3(2.5)$ & $45(37.2)$ & $16(13.2)$ & $2(1.6)$ & 1.968 & 2 & 0.374 \\
\hline $\begin{array}{l}\text { Transmitted via sharp } \\
\text { material }\end{array}$ & $47(38.8)$ & $8(6.6)$ & $3(2.5)$ & $49(40.5)$ & $10(8.3)$ & $4(3.3)$ & 0.2 & 2 & 0.905 \\
\hline $\begin{array}{l}\text { via eating raw meat together } \\
\text { with HIV positive people }\end{array}$ & $29(24)$ & $23(19)$ & $6(4.95)$ & $30(24.8)$ & $27(22.3)$ & $6(4.95)$ & 0.131 & 2 & 0.937 \\
\hline via Mosquito bite & $23(19)$ & $30(24.8)$ & $5(4.1)$ & $40(33)$ & $22(18.2)$ & $1(0.8)$ & 8.292 & 2 & 0.016 \\
\hline via pregnant woman to child & $35(28.9)$ & $11(9.1)$ & 12(9.90) & $37(30.6)$ & $17(14)$ & $9(7.4)$ & 1.566 & 2 & 0.457 \\
\hline
\end{tabular}

Respondents' knowledge on the methods of prevention of HIV/AIDS indicated that about $63.6 \%(n=77)$ of the respondents has a knowledge on using condom every time they have sex., Of these, $33 \%(n=40)$ were females and $30.6 \%(n=37)$ were males, But still now about $36.4 \%(n=44)$ of the students don't know as condom is used to prevent transmission of HIV AIDS. About $5.8 \%(n=7)$ males and $8.3 \%(n=10)$ females respondents don't know the importance of abstain in HIV prevention. In general the chi square result about knowledge of using condom and faith full to one sexual partner for HIV prevention of both sex indicate that $\left(X^{2}=2.200, p<0.333\right)$ and $\left(X^{2}=1.721\right.$, $\mathrm{p}<0.423)$ respectively. This shows that, there is no significant difference among both sexes in the study areas (Table-4).

\begin{tabular}{|c|c|c|c|c|c|c|c|c|c|}
\hline $\begin{array}{l}\text { Knowledge } \\
\text { about HIV } \\
\text { prevention }\end{array}$ & \multicolumn{3}{|c|}{ Male N (\%) } & \multicolumn{3}{|c|}{ Female N (\%) } & \multicolumn{3}{|c|}{ Chi square test $\left(\mathrm{x}^{2}\right)$} \\
\hline $\begin{array}{l}\text { Faithful to } \\
\text { sexual } \\
\text { partner }\end{array}$ & $29(24 \%)$ & $22(18.2 \%)$ & $7(5.8 \%)$ & $36(29.8 \%)$ & $17(14 \%)$ & $10(8.3 \%)$ & 1.721 & 2 & 0.423 \\
\hline
\end{tabular}

\section{DISCUSSIONS}

This study revealed that, only $37.2 \%$ of them were a habit of discussion about HIV/AIDS with their parents and about $62.8 \%$ of study participants were not discussed with their friends. This shows there is a gap in free discussion about HIV/AIDS infection with in the parents as well as with friends. The main modes of transmission of HIV known by the students were sexual intercourse $(75.2 \%)$ followed by contaminated injection needles $(79.3 \%)$ which is on similar line with study done in secondary school students in Northern Ethiopia (Melaku et al., 2014). While 
mosquitoes bite $(35.5 \%)$, touch saliva of HIV infected person $(52 \%)$ were the least. $59.5 \%$ of the respondents were answered as HIV can transmit from infected pregnant mother to child. This study shows that, even though the majority of respondents have knowledge about the transmission of HIV/AIDS from infected to uninfected, there is also knowledge gap in high school students that must be given attention to increase their knowledge, perception to avoid their misconception on transmission of HIV/AIDS from infected to uninfected. The study point out that, $72.7 \%$ of respondents agree on abstain from sexual intercourse is best way for prevention of HIV/AIDS. According to this study $62 \%$ of the study participants describe there are risk areas and conditions that increase their chance of vulnerability to HIV/AIDS infection. About $9.1 \%$ of respondents explains lack of giving more attention for HIV issues at high schools, is one factor.

\section{CONCLUSION}

The results indicate that most of the students were aware of about the methods of transmission and prevention of HIV/AIDS infection. Thus, $79.3 \%$ and $72.5 \%$ were aware of transmission through sharing unsterilized sharp material and sexual intercourse respectively. $63.6 \%$ and $72.7 \%$ of them were aware of using condom during intercourse and abstain from sexual intercourse before marriage are best mode of prevention of HIV/ AIDS infection. In spite of the high level of knowledge, there were also misconception and assumption toward the transmission methods of HIV/ AIDS infection. Among those assumed wrongly or miss conceptualized respondents, Mosquito bite $52.1 \%$, eating raw meat prepared by HIV infected person $48.8 \%$ and touching saliva or sweat of infected person are mode of transmission.

\section{REFERENCE}

Agajie, M., Belachew, T., Tilahun, T., \& Amentie, M. (2015). Risky sexual behavior and associated factors among high school youth in Pawe Woreda, Benishangul Gumuz Region. Science Journal of Clinical Medicine, 4(4), 67-75.

Huda, M. N., \& Amanullah, A. (2013). HIV/AIDS-Related knowledge among secondary school students in Bangladesh: a cross-sectional study. Advances in Infectious Diseases, 3(04), 274.

Kline, A. (2014). The effects of HIV/AIDS knowledge during adolescence: the role of this knowledge in predicting sexual behaviors and outcomes (Doctoral dissertation).

Kothari, C. R. (2004). Research methodology: Methods and techniques. New Age International.

LoBiondo-Wood, G., \& Haber, J. (2017). Nursing research-E-book: methods and critical appraisal for evidencebased practice. Elsevier Health Sciences.

Melaku, Y. A., Berhane, Y., Kinsman, J., \& Reda, H. L. (2014). Sexual and reproductive health communication and awareness of contraceptive methods among secondary school female students, northern Ethiopia: a crosssectional study. BMC Public Health, 14(1), 252.

Negash, Y., Gebre, B., Benti, D., \& Bejiga, M. (2003). A community based study on knowledge, attitude and practice (KAP) on HIV/AIDS in Gambella town, Western Ethiopia. Ethiopian Journal of Health Development, 17(3), 205-213.

Okonkwo, P. I., Fatusi, A. O., \& Ilika, A. L. (2005). Perception of peers' behaviour regarding sexual health decision making among female undergraduates in Anambra State, Nigeria. African health sciences, 5(2), 107-113

Shiferaw, Y., Alemu, A., Girma, A., Getahun, A., Kassa, A., Gashaw, A., ... \& Gelaw, B. (2011). Assessment of knowledge, attitude and risk behaviors towards HIV/AIDS and other sexual transmitted infection among preparatory students of Gondar town, north west Ethiopia. BMC research notes, 4(1), 505.

Taher, E., \& Abdelhai, R. (2011). Nurses knowledge, perceptions, and attitudes towards HIV/AIDS: Effects of a health education intervention on two nursing groups in Cairo University, Egypt. Journal of Public Health and Epidemiology, 3(4), 144-154.

World Health Organization. (2002). Research on reproductive health at WHO: Biennial report 2000-2001. World Health Organization 